\title{
SOMBRAS NUMA MANHÃ DE SOL
}

\section{(Uma leitura do conto MANHÃ DE SOL de Rubem Fonseca)}

Juarez Poletto

\begin{abstract}
"Manhã de Sol" é conto irônico e denunciador da obra de Rubem Fonseca, incluso no livro Lúcia McCartney, dos idos anos setenta, quando direitos humanos eram pouco respeitados, a malandragem imperava e a valorização do ser se dava mais pelo que parecia do que pelo que realmente era. Não que haja ocorrido mudanças para melhor hoje, tampouco que naquela época iniciaram-se os problemas, apenas constata-se a existência deles no texto inteligente e perspicaz, o que caracteriza a obra do autor até os romances atuais.
\end{abstract}

A forma chama a atenção na primeira palavra, pois inicia por letra minúscula, quebrando a tradição de que se começa parágrafo com maiúscula, além do que, "madureira" é o nome de guerra do Ladrão (me permito o maiúsculo pelo mesmo motivo que o autor usou o minúsculo).

Os nomes próprios de pessoas, todos, são escritos com minúsculas, minorando, desse modo, o ser. Dar o nome é dar-se, é mostrar a alma, identificar-se. Sendo o nome minúsculo, perde a essência, a singularidade e deixa, portanto, de representar a pessoa. Por um lado, o autor não está relatando um fato específico, ocorrido com uma pessoa em particular, mas se refere a qualquer vítima de ladrão, simbolizando uma situação, fazendo ficção, não copiando a realidade; trata-se, pois, de uma situação ideal e não real. Por outro lado, ocorre uma desvalorização do Homem, naquilo que ele tem de bem pessoal, de único, de próprio; o indivíduo, nesse caso, nada vale.

As maiúsculas, por sua vez, têm especial destaque para salientar funções, títulos, profissão das pessoas( Comissário, Pm, Guarda, Punguista, Condutor, Soldado, Torneiro Mecânico, Escrivão, Doutor, Professor, Vítima etc). Essa valorização da aparência coisifica o homem, pois lhe atribui mérito maior no que parece ser em detrimento do ser. O contraste fica no mínimo curioso, quando o nome próprio e o cargo se encontram na frase: "Entra pompeu Chefe da Seção de Vigilância da DD." "Meu nome é aristides, sou um Operário".

Não restam dúvidas de que o autor faz aqui sua crítica à sociedade capitalista, na qual o indivíduo vale pelo que produz.

Vez por outra, a palavra toda vem em maiúsculas, aí o objetivo é outro: trata-se da ênfase que o autor pretende dar a vocábulos ditos de forma mais marcante, forte ou contundente por algum personagem. É o caso de "LADRÃO! LADRÃO! SOCORRO!" ditos pela vítima, quando do ataque, ou o "DOUTOR!" expresso pelo "madureira" , tentando dramatizar sua situação e sensibilizar o" Comissário".

Destaque-se também a ausência dos travessões nos diálogos, mas há a identificação de cada fala pela nomeação do falante. Aí. após dois pontos, iniciam-se as palavras do personagem, como na peça teatral escrita, o que contribui para que o clima do conto seja uma representação da vida, não o real acontecendo. Ou seja, o conto simboliza uma verdade, sua verossimilhança é plausível, entretanto o autor se utilizou de uma técnica de relatar que torna os fatos frios, objetivos, tentando revelar a distância que há entre o envolvimento dinâmico e participativo na luta pela sobrevivência e o mecânico, metódico e cru comportamento do esquema de repressão para manter o sistema.

Forma e assunto casam perfeitamente, uma vez que Manhã de Sol traz ao leitor a denúncia do cotidiano policial em que as pessoas são reduzidas a Vítima, Punguista, Soldado, Comissário, Escrivão e Carcereiro. Pouco importa o contexto em que vivem uns e outros, valem as circunstâncias do momento. Se a vida, como um todo, é miserável; se se padece de males maiores ou menores; se os filhos passam fome; se é malandro de fato... tudo isso é de menor importância, vale mesmo lavrar o flagrante na linguagem fria, isenta e distante, que reduz cada pessoa a objeto, a peça de uma engrenagem mal lubrificada mais interessada em parecer perfeita que funcional. 
A vítima não é apenas do punguista, mas também da burocracia, que se preocupa bem mais com o criminoso que com ela, relegada a diálogos interrompidos e a ordens imperiosas: "A senhora tem que depor no flagrante." "A senhora não pode ir embora. Venha ao cartório." A vítima apenas interessa no que puder beneficiar o próprio sistema. Assim, o depoimento é importante, pois permitirá o resultado efetivo do trabalho policial e colocará a polícia como realizadora de trabalho eficaz, protagonista junto à sociedade. Tudo isso é muito irônico se se considerar que a própria vítima segurou o punguista até a chegada do policial, que quase permitiu a fuga.

Há que se considerar que a vítima grita quando agredida, mas logo que o "bandido" é preso, quer livrar-se da confusão em que se meteu, pouco importando o depoimento que condenará o agressor; chega, inclusive, a interessar-se pelo destino do criminoso, numa espécie de compreensão que se tem pelos desprezados pela fortuna. Se falta coragem para depor é porque a consciência social perturba; uma vez que a vítima tem seu dinheiro para a feira, o criminoso precisa roubá-lo. Esse comportamento revela pelo menos duas verdades: quem será a verdadeira vítima, mesmo sendo punguista? Ele se diz "Torneiro Mecânico" , certamente desempregado; será feita a justiça ou apenas será defendido o direito do privilegiado, que virou vítima circunstancial?

Outro ângulo curioso a se observar é que a polícia arma-se de todos os modos para defender sua integridade, enquanto o malandro preso usa de todas as artimanhas para safar-se do flagrante e da punição. A mentira, a falsa humildade e até a autoflagelação são artifícios do punguista para "livrar sua barra", a polícia, porém, para não ser acusada de espancamento, busca um elemento da sociedade para Ihe servir de prova e curiosamente esse indivíduo é um "Professor", por um lado confiável, por outro submisso, o que the confere a condição ideal para ser orientado e parecer fiel à verdade. Não trouxeram observador quando desceram o cassetete no punguista. A crítica ao professor é oportuna, ressalvadas honrosas exceções, uma vez que, como agente de renovação e crescimento interior das pessoas, mostrou-se, na época da presente obra, conivente com o sistema opressor, tornando-se mero reprodutor da ordem social imposta.

Rubem Fonseca faz sua crítica, sua denúncia da miséria humana mais uma vez com eficiência e desenvoltura. Não são necessárias palavras grandiloqüentes, nem termos complexos, mas, com esmero e inteligência, as palavras simples adquirem lugar, conquistam espaço literário e o autor passa sua mensagem. Não se trata de literatura deleite, a não ser que alguém aprecie dor e sofrimento, frieza e medo, mas certamente não se passa em branco diante desta irônica Manhã de Sol, com ares aparentemente tão suaves, mas camuflando em suas cores um cotidiano tão dramático. 